\title{
Turismo, Medo e Violência
}

\section{Tourism, Fear and Violence}

\section{Marcello de Barros Tomé Machado (TOMÉ MACHADO, M. de B.)}

RESUMO - Um fator limitante relevante e decisivo na escolha de um destino turístico é o medo social, caracterizado como aquele que afeta a coletividade. A violência em cidades como Rio de Janeiro e São Paulo impõe às pessoas uma sensação difusa de medo e influenciam o turismo nas referidas cidades.

Palavras-chave: Turismo; Violência; Medo; Rio de Janeiro; São Paulo.

ABSTRACT - A relevant and decisive limiting factor in choosing a tourist destination is the social fear, characterized as one which affects the community. The violence in cities like Rio de Janeiro and São Paulo creates in people a diffuse sense of fear and influence the tourism in these cities.

Key words: Tourism; Violence; Fear; Rio de Janeiro; São Paulo.

\footnotetext{
* Membro do Conselho Científico da Revista Turismo e Sociedade desde o ano 2010. Graduação em Geografia (Bacharelado e Licenciatura) e Especialização em Planejamento Ambiental pela Universidade Federal Fluminense (UFF), Mestrado em Geografia pela Universidade de São Paulo (USP), Doutorado em Geografia pela Universidade Federal Fluminense (UFF). Professor Adjunto IV do Departamento de Turismo da Universidade Federal Fluminense. Endereço para correspondência: Rua Mário Santos Braga, 30, sala 714, Campus do Valonguinho. CEP: 24020-140 - Niterói - Rio de Janeiro (Brasil). Telefones: 21 2629-9888 / 9617-9891. E-mail: marcellotome@gmail.com
} 
O medo social vem alterando profundamente o território e o tecido urbano de muitas cidades no Brasil e consequentemente a vida das suas populações, seja a população fixa (moradores) ou a população flutuante (visitantes/turistas). Nas cidades cuja violência se estabelece intensamente e que apresenta elevados índices de homicídio, os moradores e visitantes se sentem intimidados e correndo perigo.

Ameaças reais, oriundas de sujeitos reais, são contrapostas a ameaças potenciais típicas do imaginário singular coletivo, produzido pelos índices perversos da violência em algumas cidades. Este imaginário singular coletivo, vinculado à violência urbana e ao medo, contribui negativamente e de maneira decisiva na construção do estereótipo das cidades turísticas, tais como o Rio de Janeiro e São Paulo.

Uma pesquisa realizada entre os dias 24 de novembro e 8 de dezembro de 2013 pela Rede Nossa São Paulo e publicada pelo Jornal Folha de São Paulo ${ }^{1}$ indica a capital paulista como pouco ou nada segura por $91 \%$ dos moradores. Esta pesquisa ouviu 1.512 pessoas, com idade superior a 16 anos. Este resultado reflete a situação vivida em 2012 pela população da referida cidade em relação à violência. Dados divulgados no dia 25 de janeiro de 2013, pela Secretaria de Segurança Pública de São Paulo (SSP-SP) indicam que a capital paulista teve um aumento de 39,8\% no número pessoas assassinadas. Foram 1.497 vítimas de homicídio doloso em 2012, contra 1.069 durante 2011.

Os números absolutos de assassinatos na capital paulista são expressivos. No entanto, ao analisarmos os números relativos (homicídio/habitante), percebemos que a mesma se encontra entre as capitais menos violentas do país, registrando em 2012, uma taxa de aproximadamente 11 homicídios por 100 mil habitantes. Esta taxa é próxima da indicada pela Organização Mundial da Saúde (OMS), que considera a violência como epidêmica quando uma cidade supera os 10 homicídios dolosos por 100 mil habitantes.

Segundo dados do Instituto de Segurança Pública do Estado do Rio de Janeiro (ISP), a capital fluminense apresentou nos últimos 12 meses um total de 1.204 homicídios dolosos, o que representa uma taxa de 19 homicídios por 100 mil habitantes, bem acima da taxa de homicídios da cidade de São Paulo. No entanto, as taxas cariocas encontram-se em declínio. O total de homicídios dolosos na cidade do Rio de Janeiro foi de 1.417 vítimas em 2011, ou seja, 22,9 homicídios por 100 mil habitantes. Estes

\footnotetext{
${ }^{1} \mathrm{http} / / / \mathrm{www} 1$. folha.uol.com.br/cotidiano/1216236-mais-de-90-dos-paulistanos-acha-pouco-seguro-viverem-sao-paulo.shtml. Acesso em 18 de janeiro de 2013.
} 
dados indicam uma redução 15,04\% no número de vítimas de assassinato entre 2011 e 2012 na cidade do Rio de Janeiro. Neste mesmo período a cidade de São Paulo teve um aumento de 39,8\% no número de homicídios dolosos.

Políticas públicas focadas na redução da criminalidade no Brasil foram criadas e implantadas na primeira década do século XXI. Identificamos como uma das ações de maior expressão para a diminuição da violência o Programa de Desarmamento do Brasil, iniciado em 2004. Este programa teve como propósito retirar de circulação armas de fogo que se encontravam nas mãos dos cidadãos brasileiros, tais como revólveres, metralhadoras, escopetas e fuzis. O indivíduo entrega de boa-fé a arma na Delegacia de Polícia ou em Postos especiais para a coleta sem nenhum tipo de punição e tem direito a indenização, conforme a Lei 10.884 de 17/06/2004. Desde então foram entregues aproximadamente 600 mil armas, todas destruídas pelo Comando do Exército.

No caso do Rio de Janeiro, a redução da circulação de armas e outras ações voltadas à redução da violência na cidade, tais como a criação e instalação das Unidades de Polícia Pacificadora (UPP) pela Secretaria Estadual de Segurança Pública do Rio de Janeiro em favelas cariocas, propiciaram clara diminuição da violência na metrópole fluminense. Recente pesquisa revelou ser o medo da violência e da criminalidade um dos principais fatores limitantes para à escolha de um destino turístico ${ }^{2}$. Portanto, a redução da violência em uma cidade tende a ampliar sua atratividade, pois minimiza um relevante fator limitante, podendo propiciar o fomento do fluxo turístico receptivo para a mesma. Isto estaria acontecendo com o Rio de Janeiro.

Computados os dados de desembarques aéreo e marítimo, o Rio de Janeiro teria recebido em 2012 cerca de 2 milhões de visitantes estrangeiros ${ }^{3}$, o que caracteriza um aumento significativo comparado a 2011 quando a cidade recebeu cerca de $980 \mathrm{mil}$ turistas estrangeiros.

O Turismo, por ser uma atividade sujeita a externalidades, inviabiliza determinarmos a redução da violência como único fator propiciador do aumento do fluxo turístico para a cidade. Além disso, a dificuldade de mensuração do fluxo turístico

\footnotetext{
${ }^{2}$ Pesquisa realizada em 2011 pelo Grupo de Pesquisa "Turismo, Meio Ambiente Urbano e Inclusão Social" da Universidade Federal Fluminense (TURis-UFF), cujos resultados parciais foram publicados em artigo da Revista TOURISM \& MANAGEMENT STUDIES, n. 8 (2012).

${ }^{3}$ Dados obtidos junto a INFRAERO, Píer Mauá e Ministério do Turismo divulgados pela Revista Veja Rio (ano $22-$ n. 3).
} 
receptivo em uma metrópole como o Rio de Janeiro impõe incertezas quanto ao total de turistas estrangeiros que visitaram a cidade e às devidas comparações. No entanto, os questionários aplicados e as narrativas orais da pesquisa indicada anteriormente ${ }^{2}$, nos leva a acreditar e a defender a hipótese sugerida de que a diminuição da violência na cidade do Rio de Janeiro é um relevante fator para a ampliação do fluxo turístico receptivo direcionado a metrópole carioca.

A realização de eventos que acontecerão integralmente ou parcialmente na cidade do Rio de Janeiro, tais como a Jornada Mundial da Juventude, a Copa das Confederações e o Rock in Rio em 2013, a Copa do Mundo de Futebol da FIFA em 2014 e os Jogos Olímpicos em 2016, somados a redução dos índices de violência e criminalidade, tende a contribuir com a ampliação do fluxo turístico receptivo para a capital fluminense nos próximos anos.

Assim sendo, a redução da violência nos últimos anos teria possibilitado a (re)construção de uma imagem motivadora para grande parcela da demanda turística, possibilitando ao Rio de Janeiro consolidar-se como importante destino turístico. Acreditamos também que a ampliação da violência agrega elementos negativos ao estereótipo turístico de uma localidade, funcionando como fator limitante para a escolha do destino a ser visitado. Apesar de não termos verificado a redução do fluxo turístico receptivo na cidade de São Paulo, o aumento pontual da violência no ano de 2012, pode gerar mazelas significativas, entre elas, a diminuição do turismo direcionado a capital paulista Esta hipótese merece ser investigada, visando a melhor compreensão da relação turismo e violência urbana. 